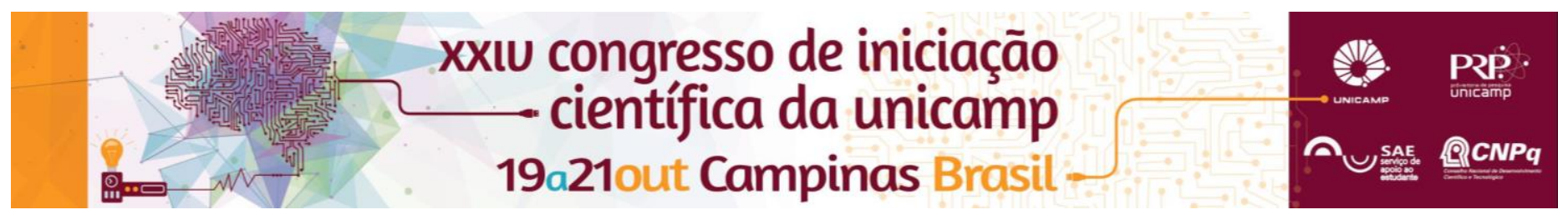

\title{
RECURSOS DE AUTOMAÇÃO APLICADOS À ARQUITETURA
}

\section{Lucas Melo De Chiara*}

\section{Resumo}

A evolução da automação industrial não só permitiu o desenvolvimento de novos ramos na indústria e engenharia, como agregou novos conceitos dentro da arquitetura, inserindo elementos de automação, e assim, culminando em estruturas que não são apenas parte do meio, mas também têm a capacidade de interagir com este.

\section{Palavras-chave:}

Fachadas Responsivas, Arquitetura Performativa, Arduino.

\section{Introdução}

A introdução de elementos de automação na arquitetura, permitiu a criação de estruturas que respondem a fatores externos, como: chuva, luz e vento, porém, em conjunto com a estética destas obras, houve uma interação com o meio ambiente, dinamizando a paisagem, e influenciando no cotidiano de quem convive com estas. Um dos desafios da engenharia é a busca por soluções mais eficientes, assim, este trabalho tem por finalidade integrar conhecimentos de engenharia do aluno, aos conceitos de arquitetura, e assim, alcançar soluções que explorem o conceito de "Fachadas Responsivas".

Inspiração para este trabalho, o Al Bahar Towers, figura 1, possui uma fachada que responde a estímulos externos e podendo ser acionada conforme necessidade, como mostra figura 2. O objetivo inicial deste trabalho era produzir um protótipo da fachada deste edifício e apresentar uma solução de automação, porem com o tempo de pesquisa reduzido para 4 meses, foi desenvolvido um protótipo mais simples, propondo uma solução que envolve elementos de programação do GrassHopper, um software muito utilizado para projetos arquitetônicos, como interface de controle, e integrando ao Arduino para realizar o controle/automação do protótipo, permitindo ao aluno explorar habilidades em áreas da mecânica, elétrica e programação com este projeto.

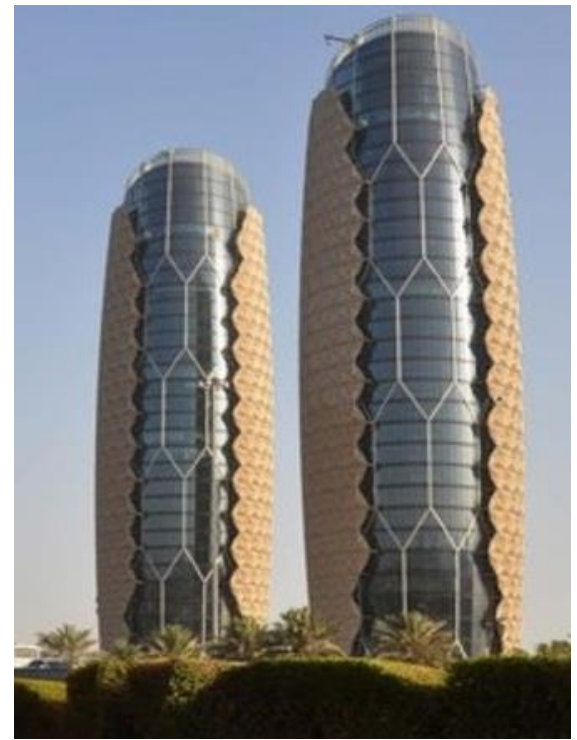

\section{Conclusões}

O conceito de "Fachadas Responsivas" representa mais que uma tendência, mas sim uma necessidade na busca de fachadas mais eficientes, indo além da estética de uma edificação, mas podendo contribuir com o edifício, proporcionando redução dos gastos com energia e ventilação, e até mesmo influenciando no cotidiano das pessoas que convivem com estas, através de estímulos na paisagem.

\section{Agradecimentos}

Aos amigos e à família pelo apoio, e à Profa. Dra. Maria Gabriela Caffarena Celani por apresentar um universo além do curso de Engenharia Elétrica.

Figura 1. Al Bahar Towers, situado em Abu Dhabi, Emirados Árabes Unidos. 